\title{
ASSESSMENT OF THE CONSERVATION STATUS OF A FRANCISCANA (PONTOPORIA BLAINVILLEI) STOCK IN THE FRANCISCANA MANAGEMENT AREA III FOLLOWING THE IUCN RED LIST PROCESS
}

\author{
Eduardo R. Secchi ${ }^{1,2, \bullet}$ and John Y. Wang ${ }^{3}$
}

\begin{abstract}
The IUCN Red List of Threatened Species is the most widely followed and comprehensive inventory of the conservation status of species. Recently, the Red List programme changed in several ways including, revisions to the criteria for determining species' statuses and the development of a process for challenging statuses. In the 2000 Red List, the franciscana (Pontoporia blainvillei) was listed as "Data Deficient", which indicates that data were insufficient to determine the status of the species under the Red List criteria but the species may be deemed to belong to a category of threat once adequate data for assessment are available. Because franciscana is possibly the cetacean species most impacted by anthropogenic activities, especially by incidental catches in gillnet fisheries in the western South Atlantic and because much data has accumulated over the last 15 years, all participants in the 4th Workshop for the Co-ordination of Research and Conservation of Franciscana in the Western South Atlantic (Porto Alegre, Brazil, 5-9 November, 2000) recommended that a reassessment of the species be performed as soon as possible. But due to the lack of the required information (from most regions) for assessment, the status of the species remains as "Data Deficient". However, in this paper, we assessed the conservation status of one franciscana stock inhabiting waters off Rio Grande do Sul State, southern Brazil and Uruguay (Franciscana Management Area III - FMA III). The available information for FMA III resulted in this stock being classified as "Endangered" under sub-criterias $1 \mathrm{~d}$ and $2 \mathrm{~d}$ of criterion A (EN A1d+2d). The intention is to provide a case study (using the best known stock) to demonstrate the types of information and documentation required for a Red List assessment following the current criteria.
\end{abstract}

Resumo - A Lista de Espécies Ameaçadas do Livro Vermelho da IUCN é o inventário sobre o estado de conservação de espécies mais abrangente e consultado. Recentemente, o programa de avaliação do estado de conservação das espécies segundo as categorias da IUCN tem passado por várias mudanças, as quais incluem uma série de critérios quantitativos de avaliação, tornando o processo mais objetivo e rigoroso. Na Lista do Livro Vermelho editado em 2000, a toninha (Pontoporia blainvillei) foi listada como "Dados Insuficientes", indicando que os dados necessários para realizar uma avaliação não estão disponíveis. Considerando que a toninha possa ser o pequeno cetáceos mais impactado por atividades antropogênicas, especialmente devido às capturas acidentais em redes de emalhe, no Atlântico Sul Ocidental e, porque uma quantidade significativa de dados tem sido produzida nos últimos 15 anos, os participantes do $4^{\circ}$ Encontro para a Coordenação de Pesquisa e Manejo da Toninha no Atlântico Sul Ocidental (Porto Alegre, Brasil, 5-9 de novembro de 2000) recomendaram que uma reavaliação para a espécie fosse feita com brevidade. Devido à falta das informações cruciais para a maioria das regiões, uma avaliação ao nível de espécie não é possível e a toninha permanence classificada na categoria "Dados Insuficientes". Entretanto, neste artigo, faz-se a avaliação do estado de conservação de um estoque de toninhas que habita as águas costeiras do estado do Rio Grande do Sul, sul do Brasil e Uruguai (Área III para o Manejo da Toninha - FMA III). As informações disponíveis para a FMA III classificam o estoque como "Ameaçado" sob os sub-critérios 1d e

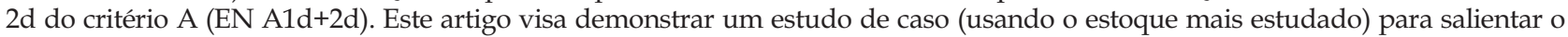
tipo de informação e documentação necessária para produzir uma avaliação seguindo os critérios atuais da IUCN.

Keywords: Franciscana, conservation, status, IUCN Red List, cetaceans, western South Atlantic

\section{Introduction}

In the past, the status of species was determined by the opinions of experts and was frequently based on limited information. By the late 1980's, with growing interest in the status of threatened species, the need for objective, rigorous criteria for determining the extinction risk and conservation status of species was recognized. And after several years of development and many draft versions, a set of quantitative criteria was adopted by the IUCN council in 1994 and then implemented in the 1996 IUCN Red List. Another important event was the formal establishment of the Red List Programme in 1998 to coordinate the once opportunistic process. Although species assessors are generally appointed by the appropriate Red List Authority (RLA; the Cetacean Specialist Group is the RLA for cetaceans), anyone can now submit to the RLA for consideration, challenges to previously assessed species or an assessment of a species that has not been assessed. However, submissions must follow the rules of the Red List and satisfy the minimum standards in documentation.

The franciscana (Pontoporia blainvillei) was listed as "Data Deficient" in the 2000 IUCN Red List of Threatened Species (IUCN, 2000). This classification does not imply a more favourable status than a listing under one of the threatened categories of "Vulnerable", "Endangered" or "Critically Endangered". Rather, it indicates that data were insufficient to determine the status of the species under the Red List criteria, and the species may be deemed to belong in any one of the categories from "Least Concern" to "Critically Endangered" once adequate data for assessment are available and an assessment is carried out. Most participants in the 4th Workshop for the Co-ordination of Research and Conservation of Franciscana in the Western South Atlantic (Porto Alegre, Brazil, 5-9 November, 2000) were uncomfortable with this "Data Deficient" classification for the franciscana. Given the availability of new information and evidence of population decline (e.g. declining by-catch and stranding rates in Uruguay and Rio Grande do Sul State

\footnotetext{
1'Laboratory of Marine Mammals, Museu Oceanográfico "Prof. Eliézer C. Rios", Universidade do Rio Grande, Cx.P. 379, Rio Grande-RS, 96200-970, Brazil. ${ }^{2}$ Marine Mammal Research Group, University of Otago, PO Box 56, Dunedin, New Zealand.

- Corresponding author: edu.secchi@xtra.co.nz.

${ }^{3}$ FormosaCetus Research and Conservation Group, 310-7250 Yonge Street, Thornhill, Ontario, CANADA, L4J-7X1
} 
waters), participants unanimously recommended that a reassessment of the species be performed as soon as possible. In this paper, we use the current Red List critieria to assess the conservation status of the franciscana stock inhabiting waters off Rio Grande do Sul State, southern Brazil and Uruguay [an area referred to hereafter as Franciscana Management Area III (FMA III) - see details below]. Our intention was to provide a case study demonstrating the types of information and documentation required for such an assessment.

\section{Overview of Range}

The franciscana inhabits shallow coastal and estuarine waters of tropical and temperate regions of the western South Atlantic Ocean. Its distribution extends from Itaúnas, Espírito Santo State in southeastern Brazil (Siciliano, 1994) to Golfo Nuevo, Chubut Province, Argentina (Crespo et al., 1998). However, the franciscana is not distributed continuously throughout its range. It seems to be extremely rare or absent in two areas of the northern part of the range between Macaé (southern Rio de Janeiro State) and Ubatuba (northern São Paulo State) and in southern Espirito Santo State (Siciliano et al., 2000). The reasons for these hiatuses are unclear, but because the species prefers shallow, turbid waters (Pinedo et al., 1989; Brownell, 1989), water transparency and depth may be among the factors (Siciliano et al., 2000).

Range States: Brazil (Espírito Santo, Rio de Janeiro, São Paulo, Paraná, Santa Catarina and Rio Grande do Sul states), Uruguay and Argentina (provinces of Buenos Aires, Rio Negro and Chubut).

\section{Main Habitat}

The species is endemic to the eastern coast of South America. Although it is found mainly in coastal marine waters and only occasionally in estuaries, it is relatively common in the Uruguayan part of the La Plata River estuary (Praderi, 1986). The franciscana is generally found in turbid waters less than $30 \mathrm{~m}$ deep (Pinedo et al., 1989; Secchi and Ott, 2000) where it feeds mainly on demersal fish species (e.g. Fitch and Brownell, 1971; Brownell, 1989; Bassoi, 1997; Zanellato, 1997; Ott, 2000; Di Beneditto and Ramos, 2001; Rodriguez et al., 2002). It does not appear to undergo large seasonal movements and little is known about daily movements (Bordino et al., 1999).

\section{Key Areas of Distribution and Population Abundance}

Morphological and molecular data strongly support the existence of two main populations of franciscana. Multivariate analysis of morphometric data revealed two geographical forms: a smaller form in the northern part of the species' range (north of $27^{\circ} \mathrm{S}$ ) and a larger form in the coastal waters of southern Brazil, Uruguay and Argentina (south of $32^{\circ} \mathrm{S}$ ) (Pinedo, 1991). Analyses of a highly variable region of mitochondrial DNA (mtDNA) also supported these two geographic forms (Secchi et al., 1998). Furthermore, Lázaro $(2000,2001)$ and Hamilton et al. (2000) compared the mtDNA of franciscanas from Uruguay and Argentina with those published by Secchi et al. (1998) and found support for the existence of a large southern population (composed of animals from Rio Grande do Sul, Uruguay and Argentina) that is clearly differentiated from animals in the waters of Rio de Janeiro. These studies revealed fixed genetic differences between the populations that suggest essentially no effective genetic exchange (see Secchi et al., 1998; Hamilton et al., 2000; Lázaro, 2001).

By applying the hierarchical classification scheme of Dizon et al. (1992) for determining the likelihood of stocks being evolutionarily significant units, Secchi et al. (in press a) proposed that the southern and northern populations of the franciscana each be divided into two management stocks. The range limits for each stock were defined as provisional Franciscana Management Areas, as follows: FMA I - coastal waters of Espírito Santo and Rio de Janeiro states, Brazil (note: confirmation of the hiatus in the Espírito Santo State with increased survey effort will require further division of this FMA); FMA II - São Paulo, Paraná and Santa Catarina states, Brazil; FMA III - coastal waters of Rio Grande do Sul State, southern Brazil and Uruguay; and FMA IV - coastal waters of Argentina, including the provinces of Buenos Aires, Rio Negro and Chubut.

There is no current abundance estimate for the species as a whole, but there is an estimate for FMA III (Secchi et al. 2001). Thirty-four franciscanas (in 29 groups) were recorded during aerial surveys of coastal waters of Rio Grande do Sul State, giving a mean density of 0.657 individuals $/ \mathrm{km}^{2}$ (95\% CI: 0.516 to 0.836 ) for the $435 \mathrm{~km}^{2}$ study area after correcting for the probability of missing submerged dolphins. Extrapolating this density to the entire stock's range would result in an estimate of 42,078 franciscanas (95\% CI: 33,047-53,542). This extrapolated result, however, should be used cautiously because it is based on a density estimate for a small fraction of the coastline, representing only $0.7 \%$ of the possible range of the stock $\left(c a 64,045 \mathrm{~km}^{2}\right)$. Furthermore, there is limited information on the distribution pattern of this species in its habitat. This estimate can nevertheless be used as a first approximation for demographic studies.

\section{Important Anthropogenic Threats}

Incidental mortality in gillnet fisheries

By far, mortality due to incidental entanglement in gillnets is the greatest threat to the franciscana in the FMA III (there is no indications of direct exploitation of the species). Bycatch in the shark gillnet fisheries of Punta del Diablo, Uruguay date to the early 1940s (Van Erp, 1969) and although gillneting in southern Brazil also began around this time (Haimovici et al., 1997), gillnet fisheries for bottomdwelling fish were only documented as a major threat to the franciscana in the 1980s. By-catch has since been 
reported from the main fishing villages along most of the stock's distribution (e.g. Moreno et al., 1997; Praderi, 1997; Secchi et al., 1997). In Uruguay, Praderi (1997) estimated that between 1974 and1994 at least 3,683 dolphins were killed. The highest and lowest annual estimates were 418 and 66 dolphins caught in 1974 and 1994, respectively. The by-catch was even higher prior to this period. In the late 1960s the annual by-catch was estimated to be as high as 1,500 to 2,000 animals (Brownell and Ness, 1970; Pilleri, 1971). Large meshsize nets targeting sharks were responsible for about 70 to $90 \%$ of the captures (e.g. Praderi, 1997; 2000). The depletion of the target shark species led to a drop in the fishing effort using these nets from almost 100\% in the 1960s and 1970s to $75 \%$ in the early 1980 s, and to only $20 \%$ in the mid 1990 s. Changes in the Uruguayan coastal fishery may be beneficial to the recovery of the franciscana from the intense by-catch pressure of the past (Praderi, 1997). However, an uncontrolled increase in fishing effort using small meshsized nets to catch bony fishes, with an associated high rate of franscicana by-catch, in adjacent areas of southern Brazil is likely to have offset or nullified any recovery. Between 1976 and 1987, 1,085 specimens were found dead (Pinedo, 1994) along the coast of Rio Grande do Sul, Brazil. By-catch values estimated from monitoring of gillnet fleets in Rio Grande do Sul State were appreciably higher, reaching several hundred per year (Secchi et al., 1997; Ott, 1998). This strongly suggests that data gathered from beach surveys should be considered cautiously when evaluating the impact of fisheries by-catch because they are a substantial underestimation of true by-catch rates (Secchi et al., 1997). Combining all information on by-catch from fleet monitoring programs and interviews results in an annual by-catch estimate of about 1,778 franciscana for the FMA III (Secchi, 1999, Secchi et al., in press b). These results might represent an underestimate of the actual by-catch for several reasons. Other fishing vessels in addition to coastal gillnetting vessels can potentially catch franciscana but were not monitored (see Secchi et al., 1997). Fishers tend to underreport by-catch (Lien et al., 1994). Furthermore, there is evidence that the by-catch estimates for southern Rio Grande do Sul State in 1994 (Secchi et al., 1997), which were used in the simulations, are lower than the current by-catch (Secchi et al., unpubl. data). Estimates of the current bycatch were obtained with the help of a research assistant from within the fishing community.

\section{Depletion of fish stocks and temporal changes in franciscana's diet}

Two important prey species of franciscana (the sciaenids Micropogonias furnieri and Macrodon ancylodon) have been exploited heavily and are currently at very low levels in southern Brazil (Haimovici et al., 1997; Haimovici, 1998). This coincides with a large reduction in the occurrence of these two species in the diet of franciscana of this region. M. ancylodon and M. furnieri decreased drastically from
$41 \%$ to $7 \%$ and $27.5 \%$ to $4 \%$, respectively (Bassoi and Secchi, 2000). In contrast, the frequency of occurrence of the cutlassfish, Trichiurus lepturus, and another sciaenid, Umbrina canosai, in the diet of the franciscana has increased from about $5 \%$ to $39 \%$ and from about $3 \%$ to $20 \%$, respectively, between the late 1970s and the mid 1990s. T. lepturus and Cynoscion guatucupa represent $47 \%$ of the total estimated bony fish biomass in this region (Haimovici et al., 1996) but these species have only experienced moderate fishing pressure (Haimovici et al., 1997; Haimovici, 1998). The latter species has always been the most important prey for franciscana but $T$. lepturus was only of minor importance in the past. Now, T. lepturus is the second most important prey species for franciscana in this region. Although the effects of this major dietary change on the franciscana are unknown, the energetic implications might be of some concern.

\section{Potential Additional Threats}

Ingestion of debris

Analysis of stomach contents of franciscana from Rio Grande do Sul State, southern Brazil (Bassoi, 1997) has shown considerable ingestion of many kinds of debris including: discarded fishing gear, cellophane and plastic fragments. The effects of such debris ingestion on health status of individual franciscanas have not been determined, and the population-level implications are uncertain. However, it is possible that debris is having a negative effect in at least some areas.

\section{Chemical pollution}

Coastal oil spills have affected other marine species (e.g. penguins and pinnipeds) but their effects on franciscana seem to be minimal. Trace metals $(\mathrm{Fe}, \mathrm{Cu}, \mathrm{Zn}, \mathrm{Mn}$ and $\mathrm{Cd}$ ) and chlorinated hydrocarbons have been found in the tissues of franciscana (O'Shea et al., 1980; Castello et al., 2000; Gerpe et al., 2002; Lailson-Brito, et al., 2002) but the levels of these contaminants are relatively low, possibly because the species' diet is composed largely of juvenile fish (UNEP/CMS, 2000).

\section{Population Trends*}

Potential rate of stock increase versus by-catch rates

The effects of incidental capture on franciscana stock FMA III were simulated using available data on abundance and by-catch, and on the rate of population increase (ROI) based on the value obtained for killer whales (i.e. 3\% - Brault and Caswell, 1993). Bottlenose dolphins and killer whales are the only odontocete species for which population growth rate estimates based on observed trends in abundance data are available. We opted to use ROI of killer whales instead

\footnotetext{
" The word "population" refers to the stock of the FMA III.
} 
of bottlenose dolphins because the latter comes from a population that have not been depleted (Wells and Scott, 1990) so maximum ROI is unlikely to occur. The simulation was used to evaluate whether the population's rate of increase could compensate for removals due to by-catch. To estimate the removal rate for the stock, the mean abundance estimate (i.e. 42,078 franciscanas) was combined with the annual by-catch estimates. Since bycatch of franciscana is likely to be negatively biased (Secchi et al., 1997; Secchi et al., in press b) the higher estimated annual by-catch for the area (i.e. 1,778 franciscanas) was used. The by-catch rate used for this simulation was $4.2 \%$. Population size was projected for 24 years or 3 generations of 8 years. Generation time was calculated using Caswell's equation that matches the IUCN definition of the average aged adult of the current cohort (Caswell, 1989). The projection predicted the stock to decline $55 \%$ within this time period.

\section{Other Evidences of Decline}

\section{Trends in CPUE of franciscana in Uruguay}

Praderi's (1997) review of the by-catch data from Uruguay between 1974 and 1994 showed a high inter-annual fluctuation. However, when the by-catch data was correct for fishing effort, the resulting CPUE of franciscana generally decreased over the 20 -year period. This trend becomes more evident if the estimates of the annual bycatch of the late 1960s and early 1970s are considered (Figure 1). In the absence of any data on fishing effort, it was assumed that the amount of fishing in the late 1960s was higher (twice the largest effort) than the early 1980s. Therefore, the CPUE of franciscana for the mid 1980s was
$80 \%$ lower than that predicted for the 1960s. Temporal changes in fishing grounds or increased fishing effort could be possible explanations for the observed decline in CPUE However, there were no major changes in fishing grounds prior to the decline of the shark fishery (i.e. mid 1980s), and fishing effort actually decreased during this same period (Praderi, 1997). The slight increase in CPUE observed in the mid to late 1980s is likely due to the decline of the shark fishery, which forced fishers to move closer to shore, where franciscanas are more abundant, to target bony fish (Praderi, 1997).

\section{Trends in stranding rates in southern Brazil}

Long-term trends in fishing effort in the coastal bottom gillnet fishery were compared to long-term stranding rates of franciscana in southern Brazil (Pinedo and Polacheck, 1999). Stranding rates prior to 1990 were on average over three times higher and significantly different from those after 1990 (two-way ANOVA; $p=0.001$ ). The results presented by Pinedo and Polacheck (1999) also suggested that stranding rates declined markedly from the late 1970s and early 1980s to the 1990s where they have remained low and relatively stable. A decline of nearly $70 \%$ in stranding rates was observed in about 20 years. Despite the difficulties of interpreting stranding rates, associated with the fact that various factors could affect the chances of a discarded by-caught carcass being washed ashore, stranding rates may reflect general trends in total kills of franciscana. If so, a decline in franciscana abundance is the most likely explanation for the declining or stable stranding rates observed during a period of increased coastal gillnet fishing effort (see Pinedo and Polacheck, 1999 for further details).

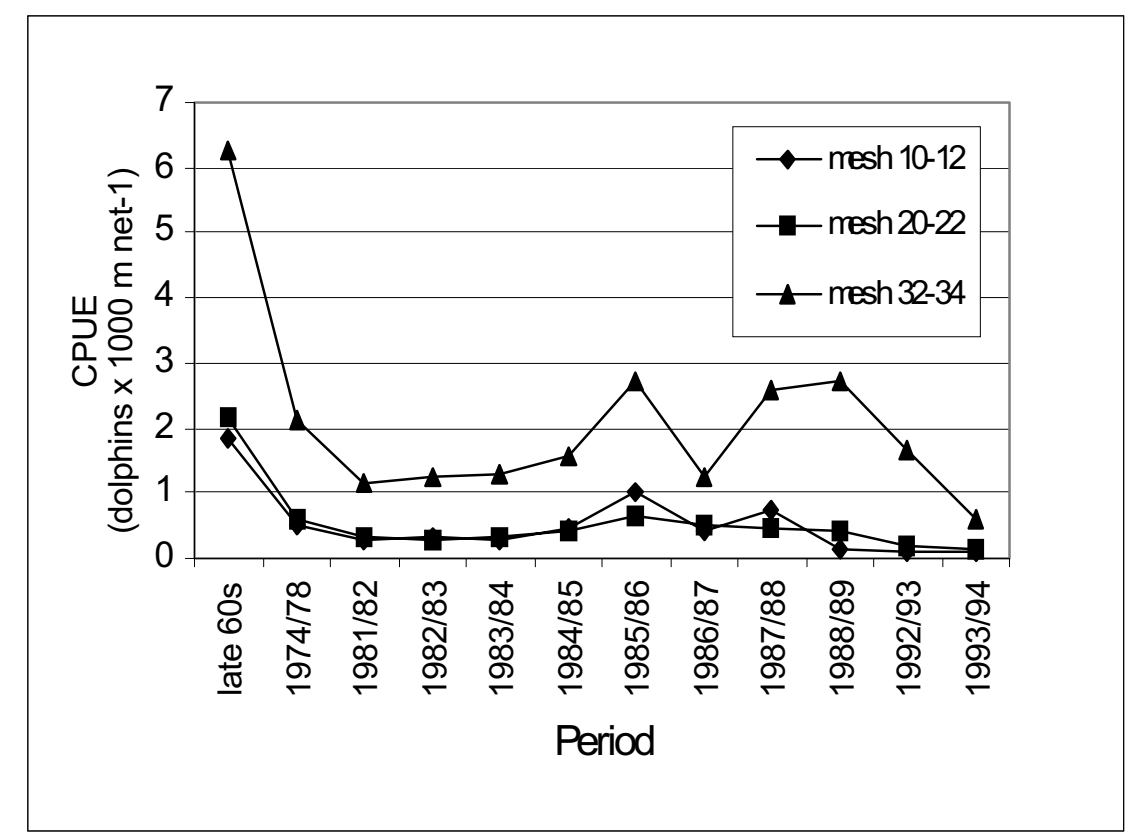

Figure 1. Long-term temporal trends in franciscana CPUE off Uruguay detailed by mesh size (obtained from Secchi $e t a l$., in press $b$ ). Source: (Brownell and Ness 1970; Pilleri 1971; Praderi 1997; Praderi 2000) 


\section{Rationale for Listing}

There is much evidence supporting a decline in franciscana abundance in all FMAs. For the stock inhabiting the FMA III, simulations using rates of increase and removal projected a $55 \%$ decline over three generations, which meets the decline threshold $(50 \%$ or more decline over three generations) of criterion A2d for "Endangered" (EN). Stranding rates in southern Brazil (assumed to be a reflection of the abundance level of franciscana) have decreased by nearly $70 \%$ in about 20 years (between the 1970s and 1990s). A sharp decline in the franciscana by-catch, which is also assumed to be a reflection of the franciscana's abundance level, was also reported in Uruguay - there was an $80 \%$ reduction in the CPUE in the 1980s compared to that of the 1960s. The combination of the declining stranding rates observed in southern Brazil and the decreased CPUE found in Uruguay showed that the level of decline for FMA III satisfied the threshold of criterion A1d for the EN category. Because two separate lines of evidence supported the EN listing, we recommend an EN listing for the FMA III under sub-criterias $1 \mathrm{~d}$ and $2 \mathrm{~d}$ of criterion $\mathrm{A}(\mathrm{EN} \mathrm{A} 1 \mathrm{~d}+2 \mathrm{~d})$.

Summary of Status for the Various Taxa or Management Units

Pontoporia blainvillei - The species was not reassessed, so its status should remain as "Data Deficient".

Northern population, occurring to the north of Santa Catarina State, Brazil (Pinedo, 1991; Secchi et al., 1998) Status could not be assessed due to insufficient data.

Stock FMA I, animals from Espírito Santo to northern Rio de Janeiro - Status could not be assessed due to insufficient data.

Stock FMA II, animals from São Paulo to Santa Catarina status could not be assessed due to data deficiency.

Southern population, occurring to the south of Santa Catarina State (Pinedo, 1991; Secchi et al., 1998) - status could not be assessed due to data deficiency.

Stock FMA III, animals from Rio Grande do Sul (southern Brazil) and Uruguay - recommended status: Endangered, Criteria A1d+2d.

Stock FMA IV, animals from Argentina - status could not be assessed due to data deficiency.

The franciscana is possibly the cetacean species most seriously and immediately affected by human activities in the western South Atlantic, especially incidental mortality in gillnet fisheries. Although we presented evidence for stock decline in FMA III, there is also reason to believe that the other stocks are in similar or worse condition because: 1) there is less suitable habitat for franciscanas in FMAs I and II than in FMA III and those areas are inhabited by more individuals of other coastal small cetacean species - potential competitors with franciscanas; and 2) by-catch is most likely underestimated. In order to allow a re-assessment of the "Data Deficient" status of the franciscana, certain information is required, e.g., abundance estimates for FMA I, II and IV; assessment of by-catch in small fishing villages not currently monitored; updated estimates of reproductive parameters. We recommend that studies dedicated to obtaining these data be carried out as soon as possible. Until this information is obtained, the species classification will probably remain "Data Deficient".

\section{Conservation Measures}

In Brazil, Federal Laws 5,197 (of 03-Jan-1967) and 7,643 (of 18-Dec-1987) afford protection to fauna and prohibit the capture and disturbance of cetaceans in its jurisdictional waters. The franciscana also appears in the Official List of Brazilian Fauna Species Threatened with Extinction (IBAMA, 1989). Regionally, the species was added recently to the list of species threatened with extinction in Rio de Janeiro State (Bergallo et al., 2000) and listed as "vulnerable" in the Red Data Book of threatened species in Rio Grande do Sul State (D. Danilewicz, pers. comm.). In Uruguayan waters, Law No 16.211 states that the National Fisheries Institute is responsible for the conservation and preservation of marine mammals under Uruguayan jurisdiction. Also, Decree No 238/1998 adopts measures for the protection and conservation of marine mammals in Uruguayan waters. In Argentina, Law $\mathrm{N}^{\circ}$ $22.421 / 1981$ is the national wildlife conservation legislation and Resolution No 351/1995 prohibits hunting, capture or appropriation and transit, in federal jurisdiction, of all of cetaceans and pinnipeds, which appear in Appendix I of the Law. Regional legislation in the provinces of Buenos Aires, Rio Negro and Chubut also provides indirect protection to the franciscana. Because the legislation could negatively affect fishers' income and welfare (i.e. fishing offshore increases risks), cooperation may be minimal. Also, better knowledge of the spatial and temporal patterns of the franciscana by-catch problem is still needed before regulations on fishing practices can be proposed. Other potential alternatives may be found in modifying fishing practices (e.g. Corcuera, 1994 suggested replacing gillnets with longlines as a means to reduce bycatch in Argentine waters). Because fish stocks are also depleted, a wider management strategy that includes other marine species is needed. However, cultural and social needs of the fishing communities must also be considered to avoid further burdening the already difficult socioeconomic situation of Latin American countries. Acoustic pingers were demonstrated to have reduced the by-catch of franciscana in nets set off Cabo San Antonio, Argentina, during a short-term study (Bordino et al., in press). However, this modification to the fishing gear also resulted in an undesirable increased rate of depredation on the nets by southern sea lions. Although the use of this kind of acoustic device seems inappropriate for this region, it may be a promising alternative to reduce by-catch until other mitigating actions can be developed and implemented, especially in areas where sea lions do not occur (e.g. many small fishing villages along FMA I and II). 


\section{Acknowledgements}

We are grateful to all participants in the 4th Workshop for the Co-ordination of Research and Conservation of Franciscana in the Western South Atlantic (held in Porto Alegre, Brazil, in 2000) who critically discussed progress on franciscana research and supported our initiative to change the IUCN Red List status of this species. We are also indebted to Randy Reeves and Barb Taylor who kindly reviewed this document and provided valuable criticism. The Brazilian Council for Scientific and Technological Development (CNPq) provided a scholarship to ERS (Process 200889/98-2).

\section{References}

Bassoi, M. (1997) Avaliação da dieta alimentar de toninha, Pontoporia blainvillei (Gervais and D' Orbigny, 1844), capturadas acidentalmente na pesca costeira de emalhe no sul do Rio Grande do Sul. Bachelor Dissertation, Fundação Universidade do Rio Grande, Rio Grande. 68pp.

Bassoi, M. and Secchi, E.R. (2000) Temporal variation in the diet of franciscana Pontoporia blainvillei (Cetacea, Pontoporiidae) as a consequence of fish stocks depletion off southern Brazil. Technical Paper WP9 presented to $I V$ Workshop para a Coordenação da Pesquisa e Conservação da Franciscana, Pontoporia blainvillei, no Atlântico Sul Ocidental. 05-09 November, Porto Alegre. 5pp.

Bergallo, H. de G., Geise, L., Bonvicino, C., Cerqueira, R., D' Andrea, P.S., Esberárd, C.E., Fernandez, F.A.S., Grelle, C.E., Peracchi, A., Siciliano, S. and Vaz, S.M. (2000) Mamíferos in A fauna Ameaçada de Extinção do Estado do Rio de Janeiro. EdUERJ, Rio de Janeiro.

Bordino, P., Thompson, G. and Iñiguez, M. (1999) Ecology and behaviour of the franciscana (Pontoporia blainvillei) in Bahia Anegada, Argentina. Journal of Cetacean Research and Management 1: 213-222.

Bordino, P., Kraus, S., Albareda, D., Fazio, A., Palmiero, A., Mendez, M. and Botta, S. (in press) Reducing incidental mortality of franciscana dolphin (Pontoporia blainvillei) with acoustic warning devices attached to fishing nets. Marine Mammal Science.

Brault, S. and Caswell, H. (1993) Pod-specific demography of killer whales (Orcinus orca). Ecology 74: 1444-1454.

Brownell Jr., R.L. (1989) Franciscana Pontoporia blainvillei (Gervais and d'Orbigny, 1844). Pages 45-67 in Ridgway, S. and Harrison, R. (Eds) Handbook of Marine Mammals. Vol 5: The First Book of Dolphins

Brownell Jr., R.L. and Ness, R. (1970) Preliminary notes on the biology of the franciscana, Pontoporia blainvillei, (Cetacea: Platanistidae). Pages 23-28 in Proceedings of the Sixth Annual Conference on Biological Sonar Diving Mammals - 1969. Stanford Research Institute, Menlo Park.

Castello, H.P., Junin, M., Rotman, F. and Sartí, G.C. (2000) Análisis de Contaminantes Organoclorados y metales Pesados en Franciscana, Pontoporia blainvillei, de Argentina y Brasil. Pages 46-50 in UNEP/CMS (Eds) Report of the Third Workshop for Coordinated Research and Conservation of the Franciscana Dolphin (Pontoporia blainvillei) in the Southwestern Atlantic. UNEP/CMS, Bonn.

Caswell, H. (1989) Matrix population models: construction, analysis, and interpretation. Sinauer Associates, Sunderland, Massachusetts.
Corcuera, J. (1994) Mortality of Pontoporia blainvillei in Northern Buenos Aires Province: the threat of small fishing camps. Reports of the International Whaling Commission (special issue) 15: 291-294.

Crespo, E.A., Harris, G. and González, R. (1998) Group size and distributional range of the franciscana, Pontoporia blainvillei. Marine Mammal Science 14: 845-849.

Di Beneditto, A.P.M. and Ramos, R.M.A. (2001) Biology and conservation of the franciscana (Pontoporia blainvillei) in the north of Rio de Janeiro State, Brazil. Journal of Cetacean Research and Management 3(2): 185-192.

Dizon, A.E., Lockyer, C., Perrin, W.F., Demaster D.P., and Seisson, J. (1992) Rethinking the stock concept: a phylogeographic approach. Conservation Biology 6: 24-36.

Fitch, J.E. and Brownell Jr., R.L. (1971) Food habits of the Franciscana Pontoporia blainvillei (Cetacea: Platanistidae) from South America. Bulletin of Marine Science 21: 626-636.

Gerpe, M., Rodríguez, D. Moreno, V.J., Bastida, R.O. and de Moreno, J.E. (2002) Accumulation of heavy metals in the franciscana (Pontoporia blainvillei) from Provincia Buenos Aires, Argentina. The Latin American Journal of Aquatic Mammals (special issue) 1: 95-106.

Haimovici, M. (1998) Present state and perspectives for the southern Brazil shelf demersal fisheries. Fishery Management and Ecology 5: 277-289.

Haimovici, M., Martins, A.S. and Vieira, P.C. (1996) Distribuição e abundância de peixes teleósteos sobre a plataforma continental do Sul do Brasil. Revista Brasileira de Biologia 56: 27-50.

Haimovici, M., Castello, J.P., and Vooren, C.M. (1997) Fisheries. Pages 184-96 in Seeliger, U., Odebrecht, C. and Castello, J.P. (Eds) Subtropical Convergence Environments - the coasts and sea in the southwestern Atlantic. SpringerVerlag, Berlin.

Hamilton, H, Rosemberg, A., Corcuera, J., Monzón, F., and Brownell, R.L. (2000) Secuencias de la region control del ADN mitocondrial de la franciscana, Pontoporia blainvillei: comparacion entre poblaciones de Brasil y Argentina. Page 56 in Abstracts, IX Reunión de Trabajo de Especialistas en Mamíferos Acuáticos de América del Sur. 28 October 02 November, Buenos Aires.

IBAMA (1989) Lista Oficial das espécies de fauna brasileira ameaçada de extinção. Diário Oficial da União, 23-02-1989.

IUCN (2000) Red Data List. (IUCN-World Conservation Union: Gland.). www.redlist.org

IUCN/SSC Criteria Review Working Group (2000) IUCN Red List Categories in Report of the $51^{\text {st }}$ Meeting of the IUCN Council. (IUCN: Gland.)

Lailson-Brito Jr., J., Azeredo, M.A., Malm, O., Ramos, R.A., Di Beneditto, A.P.M. and Saldanha, M.F.C. (2002) Trace metals in liver and kidney of the franciscana (Pontoporia blainvillei) in the north coast of Rio de Janeiro State, Brazil. The Latin American Journal of Aquatic Mammals (special issue) 1: 107-114.

Lázaro, M. (2000) Utilización de marcadores moleculares para el análisis de la variación genética y estructura poblacional de la franciscana (Pontoporia blainvillei). Pages 58-61 in UNEP/CMS (Eds) Report of the Third Workshop for Coordinated Research and Conservation of the Franciscana Dolphin (Pontoporia blainvillei) in the Soutwestern Atlantic. UNEP/CMS, Bonn.

Lázaro, M. (2001) Estructura genetica poblacional de la franciscana (Pontoporia blainvillei). Master Thesis. Universidad de la República Oriental del Uruguay, Montevideo. 93pp. 
Lien, J., Stenson, G.B., Carver, S., and Chardine, J. (1994) How many did you catch? The effect of methodology on bycatch reports obtained from fishermen. Reports of the International Whaling Commission (special issue) 15: 535-540.

Moreno, I.B., Ott, P.H. and Danilewicz, D.S. (1997) Análise preliminar do impacto da pesca artesanal costeira sobre Pontoporia blainvillei no litoral norte do Rio Grande do Sul, sul do Brasil. Pages 31-41 in Pinedo, M.C. and Barreto, A.S. (Eds) Anais do $2^{\circ}$ Encontro sobre a Coordenação de Pesquisa e Manejamento da Franciscana. Ed. FURG, Rio Grande.

O'Shea, T.J., Brownell Jr., R.L., Clark Jr., D.R., Walker, W.A., Cay, M.L. and Lamont, T.G. (1980) Organochlorine pollutants in small cetaceans from Pacific and South Atlantic Oceans, November 1968 - June 1976. Pesticides Monitoring Journal 14: 35-46.

Ott, P.H. (1998) Análise das capturas acidentais de Pontoporia blainvillei (Gervais \& D'Orbigny, 1844) (Cetacea, Pontoporiidae) nas comunidades pesqueiras do litoral Norte do Rio Grande do Sul, Sul do Brazil. Master Thesis, Pontifícia Universidade Católica do Rio Grande do Sul, Porto Alegre. $121 \mathrm{pp}$.

Ott, P.H. (2000) Ecologia alimentar de toninha, Pontoporia blainvillei, no litoral norte do Rio Grande do Sul, sul do Brasil. Pages 93-95 in UNEP/CMS (Eds) Report of the Third Workshop for Coordinated Research and Conservation of the Franciscana Dolphin (Pontoporia blainvillei) in the Soutwestern Atlantic. UNEP/CMS, Bonn.

Ott, P.H., Secchi, E.R., Crespo, E.A. and Dans, S. (2000) Estrutura etária da população de Pontoporia blainvillei acidentalmente capturada pela atividade pesqueira na costa do Rio Grande do Sul - Brasil. Pages 62-64 in UNEP/ CMS (Eds) Report of the Third Workshop for Coordinated Research and Conservation of the Franciscana Dolphin (Pontoporia blainvillei) in the Soutwestern Atlantic. UNEP/ CMS, Bonn.

Perrin, W.F. and Brownell, R.L. (1989) Report of the Workshop on Biology and Conservation of the Platanistoid Dolphins. Pages 1-22 in Perrin, W.F., Brownell Jr., R.L., Zhou, K. and Liu, J. (Eds) Biology and Conservation of the River Dolphins. IUCN SSC 3, Occasional Papers, Gland.

Pilleri, G. (1971) On the La Plata dolphin Pontoporia blainvillei off the Uruguayan coast. Investigation Cetacea 3: 69-73.

Pinedo, M.C. (1991) Development and variation of the franciscana Pontoporia blainvillei. Doctoral Thesis, University of California, Santa Cruz. 406pp.

Pinedo, M.C. (1994) Review of the status and fishery interactions of the franciscana, Pontoporia blainvillei, and other small cetaceans of the Southern Brazil. Reports of the International Whaling Commission (special issue) 15: 251-259.

Pinedo, M.C. and Polacheck, T. (1999) Trends in franciscana (Pontoporia blainvillei) stranding rates in Rio Grande do Sul, Southern Brazil (1979-1998). Journal of Cetacean Research and Management 1: 179-189.

Pinedo, M.C., Praderi, R., and Brownell Jr., R.L. (1989) Review of the biology and status of the franciscana Pontoporia blainvillei. Pages 46-51 in Perrin, W.F., Brownell Jr., R.L., Zhou, K. and Liu, J. (Eds) Biology and Conservation of the River Dolphins. IUCN SSC 3, Occasional Papers, Gland.

Praderi, R. (1986). Comentarios sobre la distribución de Pontoporia blainvillei en aguas del Rio de La Plata. Pages 206-214 in Castello, H.P. (Ed.) Actas I Reunión de Trabajo de Especialistas en Mamíferos Acuáticos de América del Sur, Buenos Aires.

Praderi, R. (1997) Análisis comparativo de estadísticas de captura y mortalidad incidental de Pontoporia blainvillei en Uruguay durante 20 años. Pages 42-53 in Pinedo, M.C. and Barreto, A.S. (Eds) Anais do $2^{\circ}$ Encontro sobre a Coordenação de Pesquisa e Manejamento da Franciscana. Ed. FURG, Rio Grande.

Praderi, R. (2000) Estado actual de la mortalidad de franciscana en las pesquerías artesanales de Uruguay. Pages 13-15 in UNEP/CMS (Eds) Report of the Third Workshop for Coordinated Research and Conservation of the Franciscana Dolphin (Pontoporia blainvillei) in the Soutwestern Atlantic. UNEP/CMS, Bonn.

Rodríguez, D., Rivero, L. and Bastida, R. (2002) Feeding ecology of franciscana (Pontoporia blainvillei) in estuarine and marine waters of Argentina. The Latin American Journal of Aquatic Mammals (special issue) 1: 77-94.

Secchi, E.R. (1999) Taxa de crescimento potencial intrínseco de um estoque de franciscanas, Pontoporia blainvillei (Gervais E D'Orbigny, 1844) (Cetacea, Pontoporiidae) sob o impacto da pesca costeira de emalhe. Master Thesis, Fundação Universidade Federal do Rio Grande, Rio Grande. 152pp.

Secchi, E.R. and Ott, P.H. (2000) A profundidade como um fator determinante da distribuição de toninhas, Pontoporia blainvillei, conforme indicado pelos índices de CPUE. Pages 55-57 in UNEP/CMS (Eds) Report of the Third Workshop for Coordinated Research and Conservation of the Franciscana Dolphin (Pontoporia blainvillei) in the Soutwestern Atlantic. UNEP/CMS, Bonn.

Secchi, E.R., Zerbini, A.N., Bassoi, M., Dalla Rosa, L., Moller, L.M., and Roccha-Campos, C.C. (1997) Mortality of franciscanas, Pontoporia blainvillei, in coastal gillneting in southern Brazil: 1994-1995. Reports of the International Whaling Commission 47: 653-658.

Secchi, E.R., Wang, J.Y., Murray, B., Roccha-Campos, C.C., and White, B.N. (1998) Populational differences between franciscanas, Pontoporia blainvillei, from two geographical locations as indicated by sequences of mtDNA control region. Canadian Journal of Zoology 76: 1622-1627.

Secchi, E.R., Ott, P.H., Crespo, E.A., Kinas, P.G., Pedraza, S.N., and Bordino, P. (2001) A first estimate of franciscana (Pontoporia blainvillei) abundance off southern Brazil. Journal of Cetacean Research and Management 3: 95-100.

Secchi, E.R., Danilewicz, D., and Ott, P.H. (in press a) Applying the phylogeographic concept to identify franciscana dolphin stocks: implications to meet management objectives. Journal of Cetacean Research and Management.

Secchi, E.R., Ott, P.H. and Danilewicz, D.S. (in press $b$ ) Effects of fishing by-catch and conservation status of the franciscana dolphin, Pontoporia blainvillei in Gales, N., Hindell, M. and Kirkwood, R. (Eds) Marine mammals and humans: towards a sustainable balance. Melbourne University Press, Melbourne.

Siciliano, S. (1994) Review of small cetaceans and fishery interactions in coastal waters of Brazil. Reports of the International Whaling Commission (special issue) 15: 241-250.

Siciliano, S., Di Beneditto, A.P., and Ramos, R.M.A. (2000) Populações isoladas do boto-amarelo Pontoporia blainvillei no sudeste do Brasil - considerações sobre o uso do hábitat e aspectos de conservação. Technical Paper WP16 presented to the IV Workshop para a Coordenação da Pesquisa e Conservação da Franciscana, Pontoporia blainvillei, no 
Atlântico Sul Ocidental. 05-09 November 2000. Porto Alegre. 9pp.

UNEP/CMS (2000) Report of the Third Workshop for Coordinated Research and Conservation of the Franciscana Dolphin (Pontoporia blainvillei) in the Soutwestern Atlantic. UNEP/ CMS, Bonn.

Van Erp, I. (1969) In quest of the La Plata dolphin. Pacific Discovery 22: 18-24.

Wells, R.S. and Scott, M.D. (1990) Estimating bottlenose dolphin population parameters from individual identification and capture-release techniques. Reports of the International Whaling Commission (special issue 12): 407-415. Zanelatto, R.C. (1997) Captura acidental de toninha, Pontoporia blainvillei, (Gervais \& D'Orbigni, 1844) (Cetacea, Pontoporiidae) no litoral do estado do Paraná, Brasil. Pages 22-29 in Pinedo, M.C. and Barreto, A.S. (Eds) Anais do $2^{\circ}$. Encontro sobre a Coordenação de Pesquisa e Manejamento da Franciscana. Ed. FURG, Rio Grande. 